\title{
GROWTH PERFORMANCES AND BIOACCUMULATION OF HEAVY METALS IN ANABAS TESTUDINEUS (BLOCH, 1792) CULTURED USING DIFFERENT MARKET FEEDS
}

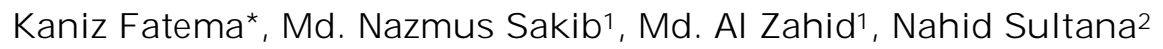 \\ and Md. Rakibul Hassan ${ }^{2}$ \\ Department of Fisheries, University of Dhaka, Dhaka-1000, Bangladesh
}

\begin{abstract}
The study was conducted to determine growth performances and bioaccumulation of $\mathrm{Cr}, \mathrm{Cu}, \mathrm{Cd}, \mathrm{Pb}$ and $\mathrm{Ni}$ in fish organs such as intestines, muscle and gills of study species after culturing them for twelve weeks by using different commercial fish feeds. The highest average daily gain (ADG, g/day) and specific growth rate (SGR; \%/day) were found in fish fed quality feed and lowest values were found in the fish fed mega feed. Best feed conversion ratio (FCR) value was found in fish fed quality feed among five different feeds. In cultured Koi, the concentration of heavy metals were found higher than initial concentration in fish feeds and collected fingerling samples. Heavy metal levels in cultured fish was $\mathrm{Cu}$ $>\mathrm{Pb}>\mathrm{Cr}>\mathrm{Cd}>\mathrm{Ni}$ and levels of bioaccumulation in individual organs was intestines $>$ gills $>$ muscle. The concentration of $\mathrm{Cu}, \mathrm{Pb}$ and $\mathrm{Cr}$ exceed the tolerable limit approved by FAO in fishes cultured with the experimental feeds. Considering the present study, Koi cultured with these experimental feeds may not safe for human consumption.
\end{abstract}

Key words: Growth performances, heavy metals, bioaccumulation, Koi

\section{INTRODUCTION}

Bioaccumulation is the accumulation of a contaminant into an organism, resulting either from direct uptake from the water or from ingestion (Braunbeck et al. 1998). The bioaccumulation of heavy metals in living organisms describes the processes and pathways of pollutants from one trophic level to another. Various fish species have already been used as bioindicator of heavy metals contamination (Svobodova et al. 2004). The concentrations of heavy metals in the organs of fish showed that the aquatic environment is polluted (Farkas et al. 2000). Pollution of the aquatic environment by inorganic chemicals has been considered as one of the major threats to the aquatic organisms including fishes, mollusks, crustaceans etc. The agricultural drainage water containing pesticides, fertilizers, industrial effluents and runoff in addition to sewage effluents supply the water bodies and sediment with huge quantities of inorganic anions and heavy metals (ECDG 2002). In the aquatic food chain, fishes are one

*Author for correspondence: <kaniz@du.ac.bd>. ${ }^{2}$ Zoology Section, Biological Research Division, Bangladesh Centre for Scientific and Industrial Research, Dhaka-1205, Bangladesh

(C) 2018 Zoological Society of Bangladesh DOI: https://doi.org/10.3329/bjz.v47i1.42023 
of the most important organisms which are very sensitive to heavy metal contamination. Most of the freshwater fishes are confined to specific microhabitat within inter connected river or stream system. If such system becomes contaminated by heavy metals, fish species either shift to less polluted segment of river and stream systems or die off which ultimately disturb the food chains (Rashed 2001).

The main production systems for freshwater aquaculture in Bangladesh are extensive and semi-intensive pond polyculture of Indian major carps and exotic carps which account for $80 \%$ of the total freshwater aquaculture production. The availability of this fish is decreasing from natural system in the recent years (Shamsuzzaman et al. 2017). Ten years ago, Koi itself contributed $2.83 \%$ of the total pond catch of Bangladesh and gradually contribution declined to $0.85 \%$ (DoF 1999). The reasons behind the severe decline of Koi fishes are ecological degradation, indiscriminate use of pesticides, destruction of habitats, obstruction of breeding migration and fishing pressure etc. Bangladesh Fisheries Research Institute (BFRI) developed the induced breeding and culture technology of exotic Koi. Many hatcheries have been established in Bangladesh with a view to producing Koi fry. Specially greater Mymensingh, Gazipur and Bogra are playing prominent role in this regard.

Considering all those prospects of demand, Koi was selected to conduct this research. Many researchers have worked on the bioaccumulation of the heavy metals in Koi collected from various sources all over the world and determined different heavy metal concentration accumulated from the environment the fish lived. Therefore, the present study is important to observe growth performances and bioaccumulation of heavy metals in Koi cultured using different market feeds. The objectives of this study are: (i) to determine the heavy metal concentration in different types of commercially available fish feeds, (ii) to determine heavy metals concentration in collected Koi fingerlings, (iii) to observe the effect of different types of fish feeds on growth performance and survival rate of Koi fingerlings and (iv) to assess the bioaccumulation of heavy metals from feeds to the fish body.

\section{MATERIAL AND METHODS}

Koi fingerlings were collected from M.O. Agro-Fisheries and Hatchery, Bagean, Trishal, Mymensingh. These fingerlings were collected in a polythene bags with oxygenated water and transported to BCSIR laboratory, Dhaka for

further analysis. Five types of fish feeds were used and four of them were commercial fish feeds which were collected from different hatcheries and fish 
feed shop in Mymensingh district and other one was made at Zoology Section, BCSIR, Dhaka, Bangladesh.

Culture station: The present study was conducted jointly at the Department of Fisheries, University of Dhaka and Zoology and Soil, Agronomy and Environment Laboratory of BCSIR in Dhaka, Bangladesh.

Culture system: The experiment was conducted for three months from August, 2016 to November, 2017 in the glass aquarium of volume $(30 \times 14 \times 6$ inches) at Zoology section of BCSIR in Dhaka, Bangladesh. The feeding trials were conducted on 12 aquaria and groups of 20 Koi fingerlings having similar body length and weight was selected and randomly stocked to each aquarium with a duplicate for each experimental diet. Before stocking the fingerlings, each aquarium was cleaned up and prepared with all the facilities necessary to run the experiment efficiently. All aquaria were filled with 60 liters clean tap water and water was changed once in a week. To supply adequate oxygen into the aquaria, aeration was done properly by setting up aerator in each aquarium. The feces and other dirt in each aquarium were removed and dead fingerlings were counted and removed before feeding.

Experimental design: Four commercial feeds such as mega feed, madina feed, quality feed and Saudi-Bangla feed and handmade feed (B3) were used for this study. B3 was made by mixing corn grain, wheat, spirulina, shrimp grain, soybean, fat, vitamins and minerals. Growth performances were measured by average daily gain (ADG), specific growth rate (SGR), feed conversion ratio (FCR) and wellbeing or condition factor $(\mathrm{K})$. Bioaccumulation of $\mathrm{Cr}, \mathrm{Cu}, \mathrm{Cd}, \mathrm{Pb}$ and $\mathrm{Ni}$ in fish organs such as intestines, muscle and gills of Koi were also determined.

Feeding of fish fingerlings: The fingerlings in each aquarium were fed once in a day at a fixed feeding rate. Feed was given at $10 \%$ of body weight in first 30 days of the experiment, $5 \%$ of their body in next 30 days and $3 \%$ of body weight in 60 to 90 days of the experiment.

Sampling design: Fish samples were taken every month with a fine meshed net. Individual length $(\mathrm{cm})$ was measured by using a measuring scale and weight (gm) by an electronic balance. At the end of experiment, the final length $(\mathrm{cm})$ and weight (gm) of the individual fish were also recorded.

Water quality variables: Water quality variables of tanks were monitored at every 7 days interval. Dissolved oxygen concentration (DO) and water temperature $\left({ }^{\circ} \mathrm{C}\right)$ of each tank was measured by using a portable DO meter (HANNA, HI 9146). Level of $\mathrm{pH}$ was measured by a digital $\mathrm{pH}$ meter (HANNA, HI 8424). Light intensity was measured by using a light intensity meter (NICETU, LX 801). 
Fish growth performances: The following formula was used to determine the different growth parameters:

1. Average daily gain $(\mathrm{ADG})=\frac{\mathrm{W}_{2}-\mathrm{W}_{1}}{\mathrm{~T}_{2}-\mathrm{T}_{1}}$

2. Specific growth rate $(\mathrm{SGR})=\frac{\mathrm{In} \mathrm{W}_{2}-\text { in } \mathrm{W}_{1}}{\mathrm{~T}_{2}-\mathrm{T}_{1}} \times 100 \%$

3. Feed conversion ratio $(\mathrm{FCR})=\frac{\text { Feed }(\mathrm{g}) \text { consumed by the fish }}{\text { Weight }(\mathrm{g}) \text { gain of the fish }\left(\mathrm{W}_{2}-\mathrm{W}_{1}\right.}$

4. Condition factor $(K)=\left(\mathrm{W} / \mathrm{L}^{3}\right) \times 100$

where, $\mathrm{W}_{2}=$ Final body weight $(\mathrm{g})$ of fry at time $\mathrm{T}_{2}$ (day), $\mathrm{W}_{1}=$ Initial body weight (g) of fry at time $\mathrm{T}_{1}$ (day), $\mathrm{W}=$ Body weight in gram, $\mathrm{L}=$ Body length in centimeter.

Determination of heavy metal: To determine the initial concentration of heavy metals in collected fingerlings, whole sample was taken because fingerlings were too small. The samples were processed for heavy metal determination according to Huq and Alam (2005). At first $1 \mathrm{gm}$ of the feed samples was taken and $10 \mathrm{ml}$ nitric acid was mixed with the samples. Then the mixture was kept in the fume chamber and digested at $120^{\circ} \mathrm{C}$ for $6 \mathrm{hrs}$. The digested samples were diluted to $50 \mathrm{ml}$ with deionized water and the solution was filtered and collected into clean and sterilized plastic bottles. Then heavy metals $(\mathrm{Cr}, \mathrm{Cu}, \mathrm{Cd}$ and $\mathrm{Ni}$ ) were detected using Atomic Absorption Spectrometer (Model No.: AA-7000, Shimadzu). After 90 days culture, liver, gills and muscle samples were collected from the fishes and heavy metal concentration was determined using the same procedure. In case of heavy metal determination of fish feeds, the samples were not needed to be dried and sample preparation was same as fish sample preparation. Heavy metal was determined by using the following formula: Concentration of heavy metals $=($ Reading - blank reading $) \times$ PDF $\times$ SDF; where, primary dilution factor $(\mathrm{PDF})=$ Volume/weight of sample, and secondary dilution factor $(\mathrm{SDF})=$ Secondary volume/secondary weight of sample. Heavy metals concentrations were expressed as $\mathrm{ppm}(\mathrm{mg} / \mathrm{kg})$.

Data analysis: The data of water quality parameters, weight and length, specific growth rate, survival rate of the fingerling, and concentration of different heavy metals were analyzed by ANOVA with the level of significance at $p<0.05$ using statistical software SPSS (SPSS version 20). The data were statistically tested to observe whether the influence of different treatments on the growth of fishes was significant or not. 


\section{RESULTS AND DISCUSSION}

Growth performances: Different growth parameters such as ADG, SGR, FCR, $K$ were determined in Koi using five different feeds. The highest ADG (g/day) and SGR (\%/day) were found in fish fed quality feed and lowest values were found in the fish fed mega feed. Best FCR value was found in fish fed quality feed among five different feeds. The highest condition factor was found in fish fed Saudi Bangla feed.

Table 1. Growth performances (MEAN \pm SEM) of Koi (Anabas testudineus) cultured for three months with five different treatments

\begin{tabular}{lcccc}
\hline \multirow{2}{*}{ Treatment } & \multicolumn{4}{c}{ Growth parameters } \\
\cline { 2 - 5 } & $\begin{array}{c}\text { Average daily } \\
\text { gain (ADG) }\end{array}$ & $\begin{array}{c}\text { Specific growth } \\
\text { rate (SGR) }\end{array}$ & $\begin{array}{c}\text { Feed conversion } \\
\text { ratio (FCR) }\end{array}$ & $\begin{array}{c}\text { Condition } \\
\text { factor }(K)\end{array}$ \\
\hline Mega feed & $0.03 \pm 0.02$ & $1.83 \pm 0.08$ & $2.44 \pm 0.24$ & $2.36 \pm 0.11$ \\
Madina feed & $0.06 \pm 0.16$ & $2.25 \pm 0.23$ & $2.09 \pm 0.23$ & $2.20 \pm 0.07$ \\
Quality feed & $0.16 \pm 0.03$ & $3.49 \pm 0.63$ & $1.51 \pm 0.29$ & $1.86 \pm 0.08$ \\
Saudi Bangla & $0.07 \pm 0.08$ & $2.40 \pm 0.67$ & $1.92 \pm 0.39$ & $2.88 \pm 0.29$ \\
Handmade feed (B3) & $0.09 \pm 0.02$ & $2.28 \pm 0.06$ & $2.13 \pm 0.18$ & $2.51 \pm 0.24$ \\
\hline
\end{tabular}

Saad et al. (2009) showed that the average daily weight gain of tilapia increased gradually reaching its maximum of $0.29,0.41$ and $0.38 \mathrm{~g}$ at the end of the experimental period for 20,25 and $30^{\circ} \mathrm{C}$, respectively. It decreased reaching $0.16 \mathrm{~g}$ at $15^{\circ} \mathrm{C}$. Hossain and Parween (1998) have recorded the highest SGR (1.8\%) in Heteropneustes fossilis by supplemental diet which is similar to the present finding in the fishes fed Madina feed (1.825). Wing-Keong et al. (2000) reported SGR as $1.27 \%$ /day with $5 \%$ feeding BW/day in Bagrid catfish and the range of SGR in the present study is $1.83-3.49 \%$. Marimuthu et al. (2010) detected relatively better FCR value $(1.6 \pm 0.08)$ by feeding catfish twice a day which is similar to the present study in fishes fed quality feed $(1.86 \pm 0.08)$. Rahman et al. (1997) showed the survival and growth of catfish after giving supplementary feeds found the values of condition factor 0.81 to 0.87 .

Heavy metals in feeds: In collected fish feeds, the concentration of lead $(\mathrm{Pb})$ was found lowest among different heavy metals in collected fish feeds. The highest concentration of $\mathrm{Pb}$ was found $(4.91 \mathrm{mg} / \mathrm{kg})$ in Madina feed. The highest concentration $(0.58 \mathrm{mg} / \mathrm{kg})$ of $\mathrm{Cr}$ was recorded in Madina feed and the lowest was recorded in mega feed and B3 feed. The highest concentration $(0.68 \mathrm{mg} / \mathrm{kg})$ of Cd was recorded in Madina feed and the lowest $(0.12 \mathrm{mg} / \mathrm{kg})$ was recorded in mega feed. The highest concentration of $\mathrm{Cu}(18.25 \mathrm{mg} / \mathrm{kg})$ was found in B3 feed and the lowest was in Madina feed. The highest value of nickel $(33.42 \mathrm{mg} / \mathrm{kg})$ 
was found in Madina feed and the lowest $(1.72 \mathrm{mg} / \mathrm{kg})$ was recorded in mega feed (Table 2).

Table 2. Concentration of different heavy metals in collected sample of fish feeds

\begin{tabular}{lllccc}
\hline \multirow{2}{*}{$\begin{array}{l}\text { Heavy metals } \\
\text { conc. }(\mathrm{mg} / \mathrm{kg})\end{array}$} & \multicolumn{5}{c}{ Treatments } \\
\cline { 2 - 6 } & Mega feed & Madina feed & Quality feed & Saudi-Bangla feed & Handmade feed (B3) \\
\hline Lead $(\mathrm{Pb})$ & 0.67 & 4.92 & 0 & 0 & 0 \\
Chromium $(\mathrm{Cr})$ & 0 & 0.58 & 1.04 & 0.35 & 0 \\
Cadmium (Cd) & 0.12 & 0.68 & 0.26 & 0.67 & 0.23 \\
Copper (Cu) & 8.21 & 4.24 & 15.55 & 11.35 & 18.25 \\
Nickel (Ni) & 1.72 & 33.42 & 14.89 & 10.94 & 10.39 \\
\hline
\end{tabular}

The result showed that there had been noticeable amount of different heavy metals in fish feeds. The concentrations of $\mathrm{Cu}$ and $\mathrm{Pb}$ were higher than the other heavy metals. The permitted lead content in feed ingredients is $10 \mathrm{mg} / \mathrm{kg}$ (WHO 1985). This study showed that the highest concentration was recorded 4.92 $\mathrm{mg} / \mathrm{kg}$ in Madina feed which is within the approved limit of WHO (1985). It is a common phenomenon in the largest tanning area of the country for over the last several years, at Hazaribagh tannery area at the southeast part of Dhaka city. One of the major concerns of these activities is the heavy metals, especially $\mathrm{Cr}$, used in the tanning processes (Maruf et al. 2007). According to FAO (1983) the acceptable limit of $\mathrm{Cr}$ is $1.0 \mathrm{mg} / \mathrm{kg}$. The concentration $(1.04 \mathrm{mg} / \mathrm{kg})$ of $\mathrm{Cr}$ was recorded in quality feed which was highest among different experimental feeds. The lowest value $(0.00 \mathrm{mg} / \mathrm{kg})$ of chromium was observed in mega feed and handmade feed (B3). The concentrations of $\mathrm{Cr}$ in quality feed are above the acceptable limit. The permissible cadmium concentration in feed ingredients of plant origin according to the current regulations is $1 \mathrm{mg} / \mathrm{kg}$ and in those of animal origin $2 \mathrm{mg} / \mathrm{kg}$ (FAO 1983). The lowest concentration $(0.12 \mathrm{mg} / \mathrm{kg})$ of Cd was found in mega feed and the highest concentration of $0.68 \mathrm{mg} / \mathrm{kg}$ was found in Madina feed. Therefore, this study found that the concentration of $\mathrm{Cd}$ is within acceptable limit. The allowable limit of concentration of $\mathrm{Cu}$ as a food ingredient is $30 \mathrm{mg} / \mathrm{kg}$ (FAO 1983). This study showed that the concentration $(18.25 \mathrm{mg} / \mathrm{kg})$ of $\mathrm{Cu}$ was found in handmade feed (B3) which was the highest among other feeds and the lowest concentration $(4.24 \mathrm{mg} / \mathrm{kg})$ of $\mathrm{Cu}$ was recorded in Madina feed. So, this study showed that the concentrations of Copper in different experimental feeds are in permitted limit. In the current regulations there are no maximum allowed concentrations of nickel for feed ingredients and compound feed. The limits for the allowed nickel content in different human foods range between 0.1 and $8 \mathrm{mg} / \mathrm{kg}$ (Alexieva et al. 2007). The 
concentrations of $\mathrm{Ni}$ in all of the experimental feeds are above the acceptable limit except mega feed.

Heavy metals bioaccumulation: Initial concentration of different heavy metals in collected Koi fingerlings (pull sample) was determined by Atomic Absorption Spectrometer (AAS). Among different heavy metals in collected Koi fingerlings, the concentration of $\mathrm{Cu}$ was found to be the highest $(2.99 \mathrm{mg} / \mathrm{kg})$ followed by $\mathrm{Cr}$ and Cd (Fig. 1).

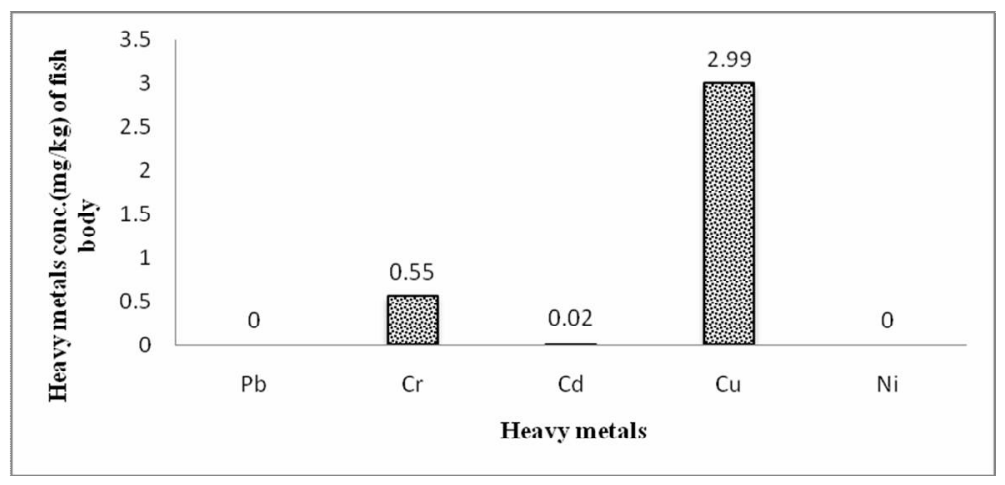

Fig. 1. Concentration of different heavy metals on collected fingerlings of Koi.

The concentration of $\mathrm{Cr}$ in gills was found the highest and the lowest in mega feed and handmade feed (B3), respectively. The concentration of $\mathrm{Cr}$ in muscle was found the highest and the lowest in mega feed and saudi bangla feed respectively. The concentration of $\mathrm{Cr}$ in intestine was not found in those feed. (Fig. 2).

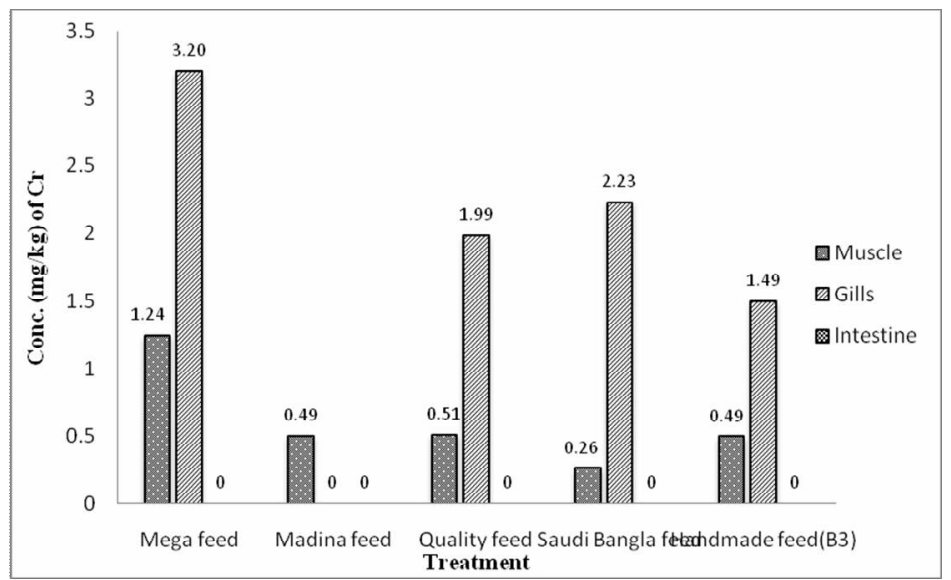

Fig. 2. Concentration of chromium in different organs of cultured Koi in five treatments. 
The concentration of $\mathrm{Cu}$ in intestines was found the highest in madina feed and the lowest in quality feed. In muscle, the highest concentration of $\mathrm{Cu}$ was observed of cultured fish receiving handmade feed (B3) and the lowest in Koi taking quality feed. The highest concentration of $\mathrm{Cu}$ in gills was found in fishes given B3 feed and the lowest in Saudi-Bangla feed (Fig. 3).

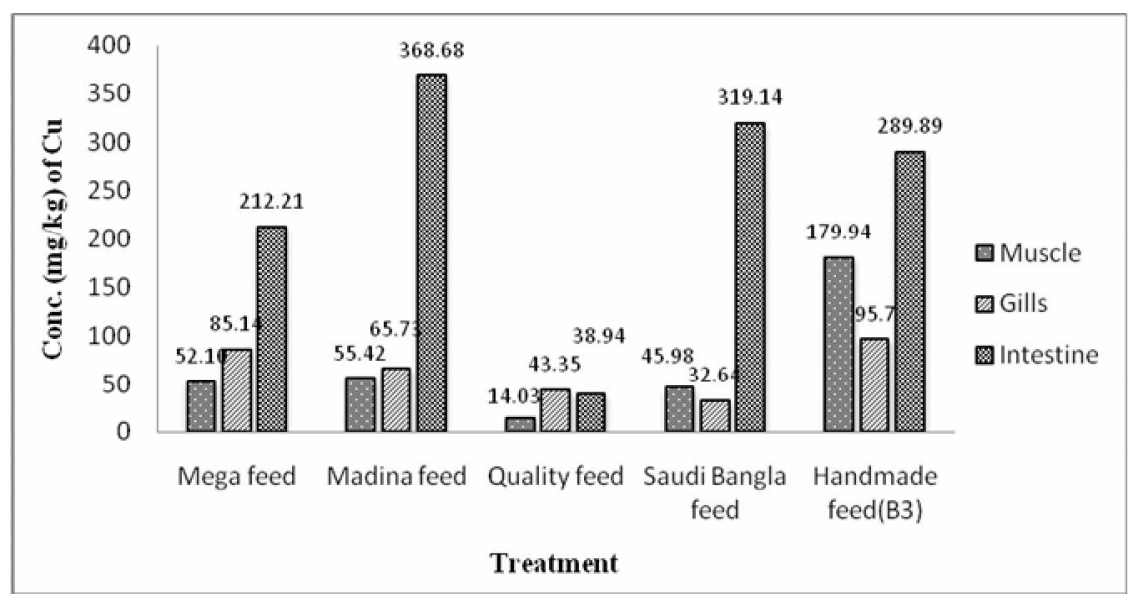

Fig. 3. Concentration of the copper in different organs of cultured Koi in five treatments.

The concentration of $\mathrm{Cd}$ in intestines was found the highest in Saudi-Bangla feed and the lowest in mega feed. In muscle, the highest concentration of Cd was observed of cultured fish receiving mega feed and the lowest in Koi taking quality feed. The highest concentration of $\mathrm{Cd}$ in gills was found in fishes given B3 feed and the lowest in Saudi Bangla feed (Fig. 4).

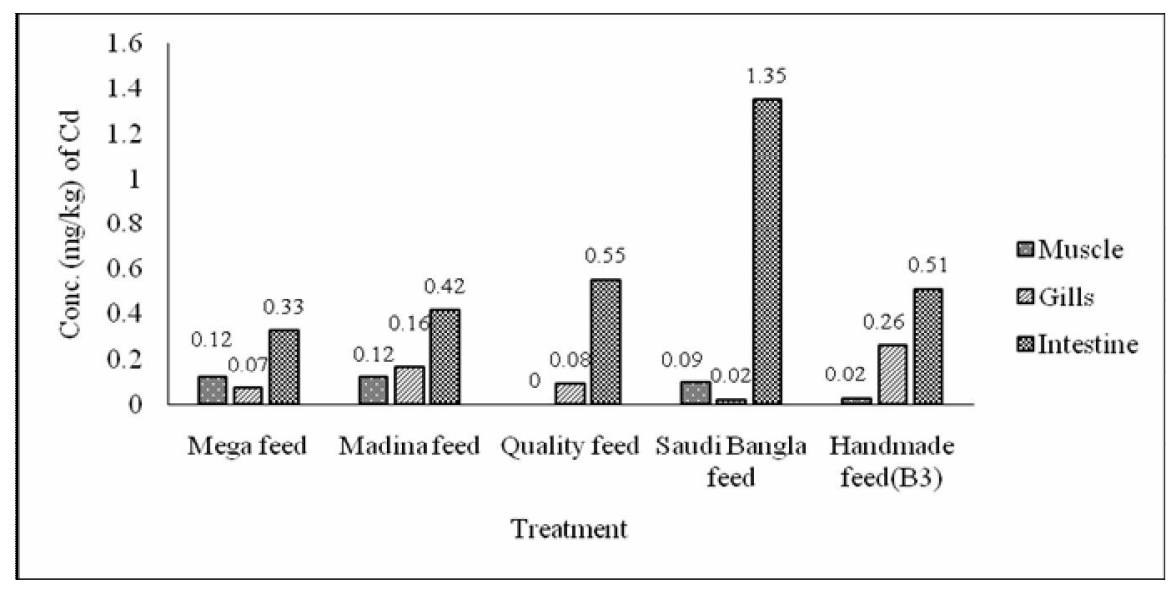

Fig. 4. Concentration of $\mathrm{Cd}$ in different organs of cultured Koi in five different treatments. 
The highest concentration of $\mathrm{Pb}$ in intestines found in Madina feed and lowest was found in quality feed. The highest concentration of $\mathrm{Pb}$ in gills was observed in fishes taken mega feed and lowest in fishes receiving Saudi-Bangla feed (Fig. 5).

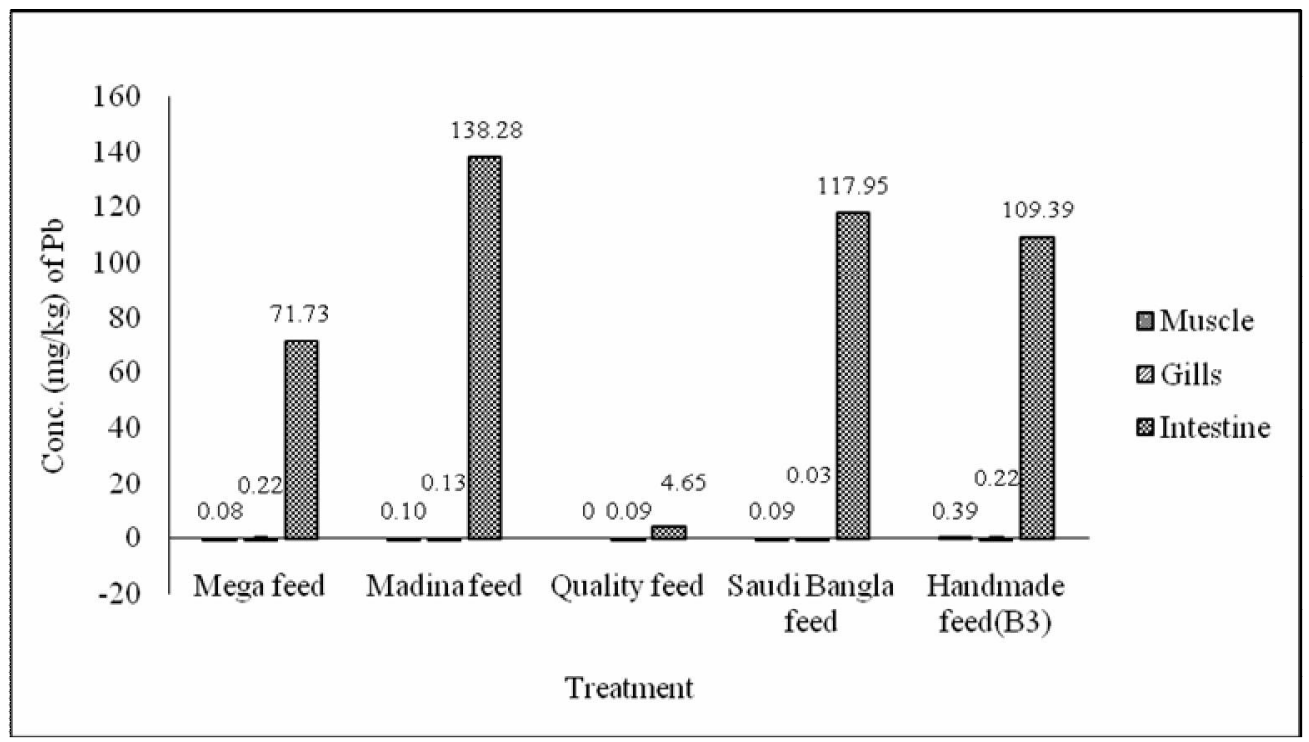

Fig. 5. Concentration of lead in different organs of cultured Koi under five treatments.

In cultured Koi, the concentration of studied heavy metals were found higher than initial concentration in fish feeds and collected fingerling samples. So bioaccumulation has occurred in cultured fishes from experimental feeds and water used for culture. Heavy metal levels in cultured fish followed the ranking: $\mathrm{Cu}>\mathrm{Pb}>\mathrm{Cr}>\mathrm{Cd}>\mathrm{Ni}$ and as expected bioaccumulation was observed highest in intestines followed by gills and muscle. The concentration of $\mathrm{Cu}, \mathrm{Pb}$ and $\mathrm{Cr}$ exceed the tolerable limit in fishes cultured with the experimental feeds. The concentrations of $\mathrm{Cd}$, and $\mathrm{Ni}$ were below the permissible range approved by FAO. According to FAO the permissible limit of $\mathrm{Cr}$ is $1.00 \mathrm{mg} / \mathrm{kg}, \mathrm{Cu}$ is $30 \mathrm{mg} / \mathrm{kg}$ and $\mathrm{Pb}$ is $10 \mathrm{mg} / \mathrm{kg}$. The present study showed that concentration of $\mathrm{Cr}, \mathrm{Cu}, \mathrm{Pb}$ were significantly higher than the permissible limit in every organ studied.

The highest concentration of $\mathrm{Ni}$ in intestine found in handmade feed (B3) and the lowest was found in Madina and Saudi-Bangla feeds. Ni concentration in gills was higher in mega feed. The highest concentration of $\mathrm{Ni}$ in muscle was observed in fishes taken handmade feed (B3) and the lowest in fishes receiving different feeds (Fig. 6). 


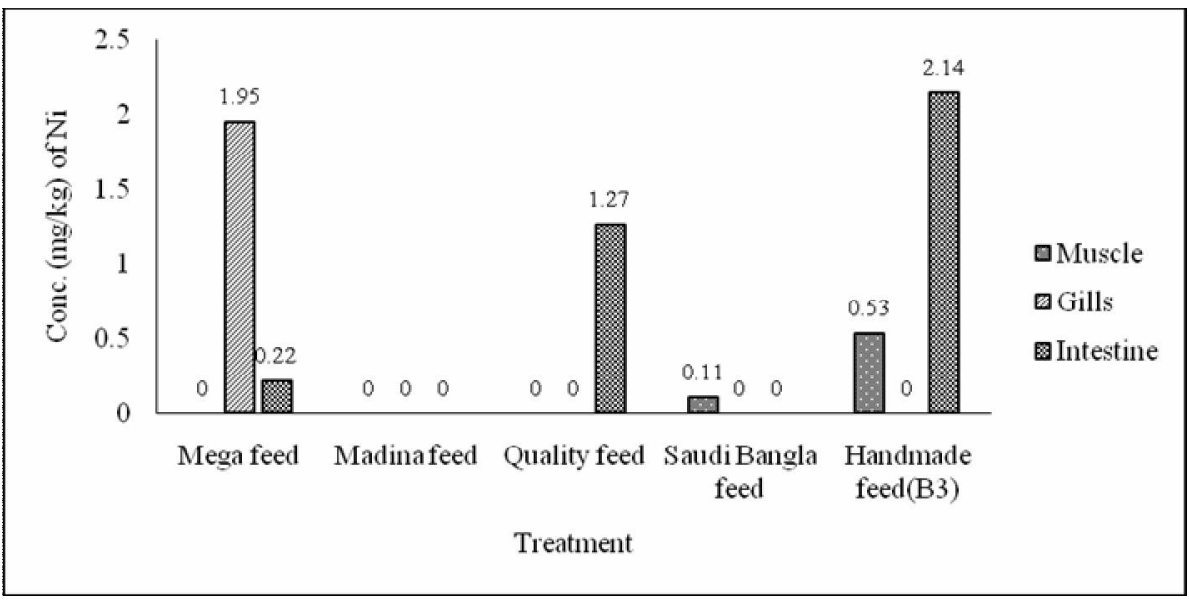

Fig. 6. Concentration of $\mathrm{Ni}$ in different organs of cultured Koi under five treatments.

Atli and Canli (2011) indicated that kidney displayed the higher capacities on metal accumulation and metal-binding protein synthesis in O. niloticus. Peyghan et al. (2003), and Soedarini et al. (2012) pointed out that liver is the key site for accumulating $\mathrm{Cu}$ and controlling homeostatic. Gill regulation is a timedependent acclimation characterizing by both how quickly the acclimation is activated to prevent further effects and how long the acclimation stays in place (Diamond et al. 2006). Fernandes et al. (2008) assessed As, Pb, Cd, Cr, Zn, and $\mathrm{Cu}$ in the muscle, gill, stomach, intestine, and liver of Heteropneustes fossilis caught at three different stations in the Buriganga river. Significant differences in concentrations of analyzed elements were observed among different tissues, but not among the stations. The author also showed that the liver appeared to be the main heavy metal storage tissue, whereas the muscle had the lowest levels of analyzed metals. The concentrations of metal in the muscles did not exceed the acceptable level as a source of food for human consumption.

\section{CONCLUSION}

The concentrations of heavy metals like $\mathrm{Pb}, \mathrm{Cu}, \mathrm{Cd}, \mathrm{Ni}, \mathrm{Cr}$ in commonly used commercial feeds in Bangladesh found higher than the permissible limit set by FAO (1983) and WHO (1985). The presence of the heavy metals in fish feeds could be observed due to uses of tannery wastes, industrial wastes to produce fish and poultry feeds. The analysis of different heavy metals in cultured Koi fish confirms that there is a high chance of bioaccumulation of different heavy metals in the fish body by using commonly used commercial fish feeds in aqua farms. The concentration of $\mathrm{Cu}, \mathrm{Pb}$ and $\mathrm{Cr}$ in the cultured fish body was so high. 
So it may be concluded that fish consumers are exposed to health risks because most of the hatcheries in Bangladesh used those experimental feeds for Koi culture. There is a need for the development of fish consumption guidelines; so as to help fish consumers reduce exposure to toxic pollutants such as heavy metals. Local authorities, stakeholders and environmental authorities must act to reduce pollution of the lake and improve the health status of the fish in order to alleviate an impending public health disaster. Fish gills and intestines should always be removed from fishes before cooking. Furthermore, fish intestines and gills should be removed from fishes before preserving them to avoid diffusion of the metals into surrounding tissues. The government should establish some laws regarding the production and raw materials used to produce fish and poultry feeds.

\section{LITERATURE CITED}

AlEXIEVA, D., ChOBAnOVA, S. and ILCHEV, A. 2007. Study on the level of heavy metal contamination in feed materials and compound feed for pigs and poultry in Bulgaria. Trakia. J. Sci. 5(2): 61-66.

ATLI, G. and CANLI, M. 2011. Alterations in ion levels of freshwater fish Oreochromis niloticus following acute and chronic exposure to five heavy metals. J. Turk. Zool. 35: 725-736.

BRAUNBECK, T., HINTON, D.E. and STREIT, B. 1998. Fish Ecotoxicology. Birkhauser verlag. pp. 355-358. ISBN 978-3-0348-9802-7.

DIAMOND, J.M., KLAINE, S.J. and BUTCHER, J.B. 2006. Implications of pulsed chemical exposures for aquatic life criteria and wastewater permit limits. Environ. Sci. Technol. 40: 5132-5138.

DoF - Department of Fisheries. 1999. Mathsha Pokhha Sankalan. Department of Fisheries, Ministry of Fisheries and Livestock, Government of the People's Republic of Bangladesh. 81 p.

ECDG - European Commission DG. 2002. E3 Project ENV. E.3/ETU/0058. Heavy metals in waste. Final Report.

FAO. 1983. Water quality for irrigation for agriculture, Irrigation Drainage Paper 29: 1-130.

FARKAS, A., SALANKI, J. and VARANKA, I. 2000. Heavy metal concentrations in fish of Lake Balaton. Lakes and Reservoirs: Res. and Manag. 5(4): 271-279.

FERNANDES, C., FONTAÍNHAS, F.A., CABRAL, D. and SALGADO, M.A. 2008. Heavy metals in water, sediment and tissues of Liza saliens from Esmoriz-Paramos lagoon, Portugal. Environ. Monit. Assess. 136: 267-275.

HOSSAIN, M. A. and PARWEEN, S. 1998. Effect of supplementary feed on the growth of shinghi (Heteropneustes fossilis). Bangladesh J. Fish. Res. 2(2): 205-207.

MARUF, A.M.M., MONIR, T., UL-HAQUE, A.M., KAZI, M., ISLAM, S.M. and ELAHI, S.F. 2007. Heavy metal concentration in tannery solid wastes used as poultry feed and the ecotoxicological consequences. Bangladesh J. Sci. and Indus. Res. 42: 4-5

MARIMUTHU, P. C., SUTHIWONGSUNTHORN, N., SHIM, I. K. and HENG, K. L. 2010. Semiconductor device and method of forming an interposer package with through silicon vias. Washington, DC: U.S. Patent and Trademark Office.

PEYGHAN, R., RAZIJALALY, M., BAIAT, M. and RASEKH, A. 2003. Study of bioaccumulation of copper in liver and muscle of common carp Cyprinus carpio after copper sulfate bath. Aquacul. Int. 11: 597-604 
RAHMAN, M.A., BHADRA, A., BEGUM, N. and HUSSAIN, M.G. 1997. Effects of some selective supplemental feeds on the survival and growth of catfish (Clarias batrachus) fry. Bangladesh $J$. Fish. Res. 1: 55-58.

RASHED, M.N. 2001. Monitoring of environmental heavy metals in fish from Nasser lake. Environ. Int. 27: 27-33.

SAAD, W., HAN, Z., DEBBAH, M., HJORUNGNES, A. and BASAR, T. 2009. Coalitional game theory for communication networks: A tutorial. arXiv preprint arXiv:0905.4057.

SHAMSUZZAMAN, M. M., ISLAM, M. M., TANIA, N. J., Al-MAMUN, M. A., BARMAN, P. P. and XU, X. 2017. Fisheries resources of Bangladesh: Present status and future direction. Aquacul. and Fish. 2(4): 145-156.

SOEDARINI, D., KLAVER, L., ROESSINK, I., WIDIANARKO, B., STRAALEN, N.M.V. and GESTEL, C.A.M.V. 2012. Copper kinetics and internal distribution in the marbled crayfish (Procambarus sp.). Chemosp. 87: 333-338

SVOBODOVA, Z., CELECHOVSKA, O., KOLARA, J., RANDAK, T. and ZLABEK, V. 2004. Assessment of metal contamination in the upper reaches of the Ticha Orlice River. Czech J. of Animal Sci. 49(4): 458-641.

WHO. 1985. Guidelines for drinking Water Quality, Vol, 2: Health Criteria and Supporting Information, 2nd Edn, World Health Organization, Geneva.

WING-KEONG, N.G., KIM-SUN, L.U., HASHIM, R. and ALI, A. 2000. Effect of feeding rate on growth, feed utilization and body consumption of tropical Bagrid catfish. Auacul. Int. 8: 19-29.

(Manuscript received on 13 February, 2019; revised on 9 May, 2019) 